\title{
COX-2 Inhibitors in Dental Pain Management
}

\author{
Inhibidores de la COX-2 en el Tratamiento del Dolor Dental
}

\begin{abstract}
Fatima Erendida Del Muro Casas; Karina Gómez Coronado; Nelly Alejandra Rodríguez Guajardo; Manuel Varela-Parga; Jesús Alberto Luengo Ferreira \& Juan Carlos Medrano Rodríguez
\end{abstract}

DEL MURO, C. F. E.; GÓMEZ, C. K.; RODRÍGUEZ, G. N. A.; VARELA-PARGA, M.; LUENGO, F. J. A. \& MEDRANO, R. J. C. COX-2 inhibitors in dental pain management. Int. J. Odontostomat., 12(3):225-227, 2018.

ABSTRACT: Pain is a major symptom in many dental procedures. Studies show consistently that pain, including dental pain, is not effectively treated; management of pain is a critical and challenging component in dentistry. Improvement and efficacy on the treatment depends on knowing which treatments are the most effective. Knowing how well an analgesic works and its associated adverse effects is fundamental to clinical decision. The aim of this review is to provide information to the dentistry field on the treatment of dental pain specifically with COX-2 inhibitors providing a useful guide to dentist on controlling pain. Therefore, nonsteroidal anti-inflammatory drugs (NSAIDs) are the most commonly prescribed analgesic agents in surgical outpatients. Major limitations of NSAIDs are their gastrointestinal (GI) adverse events (perforation, ulceration, and bleeding), impairment of hemostatic function, and renal failure (with long-term therapy). A new class of NSAIDs, COX2 selective inhibitors (Coxibs), have been developed with the aim of reducing the GI adverse events of traditional NSAIDs while maintaining their effective anti-inflammatory and analgesic properties.

KEY WORDS: Pharmacology, cox-2 inhibitors, dental pain.

\section{INTRODUCTION}

Pain has been described as an emotional experience and sometimes subjective stimulation caused by harmfulness sensory nerve endings produced by damage, generally unpleasant, associated with tissue damage. It is the most common symptom for which patients see doctors. It appears if any tissue is injured and causes the subject to react by sometimes removing the stimulus, but damage has already taken place. Pain is defined as an unpleasant sensory and emotional experience associated with actual or potential tissue damage. It has both sensory and an affective-motivational component. The nature and severity of pain is a consequence of both the sensory events arising from tissue damage, and the affectivecognitive mechanisms. A study has shown that anxiety and stress are correlated with the reported level of pain (Ong \& Seymour, 2008).

Dental pain. Toothache and dental pain can originate from dental pulp or from periodontal ligaments. Dental pain is deep, somatic and presents a variety of central excitatory effects. Referred pain includes autonomic effects, induction of spasms and trigger points in muscles innervated by the trigeminal nerve. It is described as a dull and oppressive feeling, sometimes throbbing, burning, intense and sometimes transitory. Often, the patient finds it difficult to identify the affected dental organ and can point to the pain as coming from other dental organ in one of the arcades or on face and neck; often dental pain is confused with other backgrounds (Rodríguez Reyes et al., 2013).

Oral tissue injury activates the inflammatory process, which releases a large series of pain mediators. Mediators such as prostaglandins and bradykinins cause increased sensitivity and excitation of peripheral nociceptors, which usually have little spontaneous activity under normal conditions (peripheral sensitization). With repetitive C-fiber nociceptor stimulation from the periphery, excitatory amino acids such as glutamate and aspartate, as well as several peptides (including substance $P$ ) increase and cause activation of $\mathrm{N}$-methyl-D-aspartate receptors of the postsynaptic second-order neuron in the dorsal horn. This leads to increased responsiveness of neurons in the central nervous system and to central 
sensitization, which is responsible for the prolonged pain after dental surgery. Some of these mediators may be usefully inhibited or blocked by analgesics for example; the analgesic effect of non-steroidal anti-inflammatory drugs is primarily the result of their inhibition of the synthesis of prostaglandins and bradykinins through the inactivation of cyclooxygenase (Ong \& Seymour).

NSAID's Drugs. All NSAIDs, including traditional nonselective drugs cyclooxygenase inhibitors-1 (COX1) and subclass of selective cyclooxygenase-2 (COX-2) inhibitors, are a heterogeneous group of drugs. From the chemical point of view are organic acids that share certain therapeutic actions and adverse effects (Grosser et al., 2011). Such drugs are the source of treatment of mild to moderate pain and its use is one of the bases suggested by the World Health Organization (WHO). The action of the NSAIDs are: antipyretic, anti-inflammatory and analgesic; however, these drugs, depending on their subclass, properties and structural chemical differences, as inhibition to COX (1 or 2) enzyme, determining its greater capacity within the above three properties. Even more, the particular interest on COX-2 which has the highest participation in the anti-inflammatory and analgesic capacity (Curlin, 2004; Daniels et al., 2011).

However, peri-operative use of NSAIDs has been limited because of the associated gastrointestinal, coagulation, and renal side-effects. The selective COX2 inhibitors (e.g. celecoxib, rofecoxib, valdecoxib, parecoxib, etoricoxib and lumiracoxib) are specifically designed to inhibit the COX-2 isoenzyme, which produces the prostaglandins; almost exclusively responsible for pain, inflammation and fever, without inhibiting the constitutive COX-1. Even more, some studies suggest that selective COX-2 inhibitor reduce the incidence of gastro intestinal side effects compared with conventional NSAIDs (Chen et al., 2004; Daniels et al.; Silva et al., 2011).

Therefore, the aim of this review was to offer information to the dentistry field on the treatment of dental pain, specifically with COX-2 inhibitors, providing a useful guide to dentist on controlling different types of dental pain.

These type of drugs available on the market in Mexico, concerning to selective inhibitors of COX-2 are basically two: celecoxib and etoricoxib; and preferential to COX -2: meloxicam and nabumetone (Table I).

\section{CONCLUSION}

It is of importance the pharmacotherapeutic management of dental pain, particularly of severe intensity pain, which is also accompanied by inflammation. COX-2 inhibitors are drugs that are poorly explored and implemented in the treatment of dental pain, mainly due to its controversy regarding cardiovascular-type adverse effects. However, In other studies (Nissen et al., 2016) it was shown that despite the evidence of adverse cardiovascular outcomes in a placebo-controlled trial, resulting in the withdrawal of the selective COX-2 inhibitor rofecoxib in 2004. Therefore on the basis of a small number of events, the results of another trial suggested that

Table I. COX-2 inhibitors in dental pain management therapeutic guide.

\begin{tabular}{|c|c|c|c|c|}
\hline Drug & Dental Indications & Dosage & Presentation & Contraindications \\
\hline $\begin{array}{l}\text { CELECOXIB } \\
\text { (celebrex) }\end{array}$ & $\begin{array}{l}\text { Pain relief after } \\
\text { complicated extraction } \\
\text { or third molar surgery, } \\
\text { post-surgical and } \\
\text { alveolitis }\end{array}$ & $\begin{array}{l}\text { Initial dose: } 400 \mathrm{mg} \\
\text { in acute pain; } \\
\text { maintenance dose } \\
\text { of } 100-200 \mathrm{mg} \text { per } \\
\text { day }\end{array}$ & $\begin{array}{l}\text { Capsules of } 100 \text { and } 200 \\
\text { mg. } \\
\text { Box with } 10,20 \text { and } 30 \\
\text { capsules. }\end{array}$ & $\begin{array}{l}\text { Patients sensitive to the formula } \\
\text { itself and even any other } \\
\text { NSAIDs. } \\
\text { Asthmatic patients. }\end{array}$ \\
\hline $\begin{array}{l}\text { ETORICOXIB } \\
\text { (Arcoxia) }\end{array}$ & $\begin{array}{l}\text { Pain caused by } \\
\text { mandibular or maxillary } \\
\text { dislocation, post- } \\
\text { surgical pain treatment } \\
\text { and pulpitis. }\end{array}$ & $\begin{array}{l}\text { Depending on the } \\
\text { intensity of the pain } \\
\text { goes from } 60,90 \\
\text { and up to } 120 \mathrm{mg} \text { a } \\
\text { day. }\end{array}$ & $\begin{array}{l}\text { Coated tablets with } 60 \text {, } \\
90 \text { and } 120 \mathrm{mg} . \\
\text { Box with } 7 \text { and } 14 \text { tablets. }\end{array}$ & $\begin{array}{l}\text { Patients with hepatic dysfunction } \\
\text { Not to be used in patients with } \\
\text { cardiovascular disease and } \\
\text { patients sensitive to the formula } \\
\text { itself or any other NSAID. }\end{array}$ \\
\hline $\begin{array}{l}\text { MELOXICAM } \\
\text { (Mobic, Dolocam, } \\
\text { genérico) }\end{array}$ & $\begin{array}{l}\text { Post-extraction tooth } \\
\text { pain, mandibular and / } \\
\text { or maxillary dislocation }\end{array}$ & $\begin{array}{l}\text { Oral dose of } 7.5 \text { to } \\
15 \mathrm{mg} \text { daily. } \\
\text { Parenteral } 15 \mathrm{mg}\end{array}$ & $\begin{array}{l}7.5 \text { and } 15 \mathrm{mg} \text { tablets. } \\
\text { Suspension of } 7.5 \mathrm{mg} \text { in } \\
5 \mathrm{~mL} \text {. }\end{array}$ & $\begin{array}{l}\text { Hypersensitivity to the formula. } \\
\text { Do not administer in combinatior } \\
\text { with other NSAIDs. }\end{array}$ \\
\hline & pain and alveolitis. & $\begin{array}{l}\text { per day, oral } \\
\text { follow-up not } \\
\text { exceeding } 15 \mathrm{mg} \\
\text { per day. }\end{array}$ & $\begin{array}{l}\text { Solution for injection IM } \\
15 \mathrm{mg} \text { in } 1.5 \mathrm{~mL} \text {. }\end{array}$ & Patients with asthma. \\
\hline $\begin{array}{l}\text { NABUMETONA } \\
\text { (Naburem) }\end{array}$ & $\begin{array}{l}\text { Chronic pulpitis, post- } \\
\text { extraction pain and } \\
\text { alveolitis. }\end{array}$ & $\begin{array}{l}\text { Oral dose of } 1 \mathrm{~g} \text { per } \\
\text { day, being able to } \\
\text { increase from } 1.5 \\
\text { to } 2 \mathrm{~g} \text { per day. }\end{array}$ & 500 and $750 \mathrm{mg}$ tablets. & $\begin{array}{l}\text { Renal failure patients. } \\
\text { Do not combine with other } \\
\text { NSAIDs or with methotrexate }\end{array}$ \\
\hline
\end{tabular}


cardiovascular harm may result from the use of higherthan-approved doses of celecoxib. Subsequently, the Food and Drug Administration (FDA) allowed continued marketing of celecoxib, but mandated a cardiovascular safety trial. In the Prospective Randomized Evaluation of Celecoxib Integrated Safety versus Ibuprofen or Naproxen trial, they sought to assess cardiovascular, gastrointestinal, renal, and other outcomes with celecoxib as compared with two nonselective NSAIDs (Ahmed et al., 2014). Otherwise, another study, concluded that both cox-2 inhibitor \& non-steroidal antiinflammatory drug improve post-operative complications after odontectomy of impacted lower third molar. Cox-2 inhibitor (celebrex) had superior analgesic efficacy when compared with the traditional NSAID (ibuprofen). Also, Cox-2 inhibitor (celebrex) reported insignificant improvement in edema and trismus than NSAID (ibuprofen) (Nissen et al.).

Thus, the present review proposes a therapeutic guide for the management of dental pain in specific situations indicating the management of these drugs, providing the dental community therapeutic tools for better treatments, as a result of avoiding errors in pharmacological prescription.

DEL MURO, C. F. E.; GÓMEZ, C. K.; RODRÍGUEZ, G. N. A.; VARELA-PARGA, M.; LUENGO, F. J. A. \& MEDRANO, R. J. C. Inhibidores de la COX-2 en el tratamiento del dolor dental. Int. J. Odontostomat., 12(3):225-227, 2018.

RESUMEN: El dolor es un síntoma principal en muchos procedimientos dentales. Los estudios demuestran consistentemente que el dolor, incluido el dolor dental, no se trata de manera efectiva; el manejo del dolor es un componente crítico y desafiante en odontología. La mejora y la eficacia en el tratamiento depende de saber qué tratamientos son los más efectivos. Saber qué tan bien funciona un analgésico y sus efectos adversos asociados es fundamental para la decisión clínica. El objetivo de esta revisión es proporcionar información al campo de la odontología sobre el tratamiento del dolor dental específicamente con los inhibidores de la COX-2, proporcionando una guía útil para el control del dolor por parte del dentista. Por lo tanto, los fármacos antiinflamatorios no esteroideos (AINE) son los agentes analgésicos más comúnmente prescritos en pacientes ambulatorios quirúrgicos. Las principales limitaciones de los AINE son los eventos adversos gastrointestinales (perforación, ulceración y hemorragia), deterioro de la función hemostática e insuficiencia renal (con terapia a largo plazo). Una nueva clase de AINE, los inhibidores selectivos de la COX-2 (Coxibs), se han desarrollado con el objetivo de reducir los eventos adversos gastrointestinales de los AINE tradicionales mientras se mantienen sus propiedades antiinflamatorias y analgésicas efectivas.

PALABRAS CLAVE: Antiinflamatorios no esteroideos, Inhibidores selectivos de la COX-2, Tratamiento del dolor dental.

\section{REFERENCES}

Ahmed, S. S.; EISharrawy, E. A. \& Hamed, T. A. Clinical evaluation of Cox-2 inhibitor for management of post operative complications after odontectomy of impacted lower third molar. J. Am. Sci., 10(11):60-3, 2014.

Chen, L. C.; Elliott, R. A. \& Aschroft, D. M. Systematic review of the analgesic efficacy and tolerability of COX-2 inhibitors in postoperative pain control. J. Clin. Pharm. Ther., 29(3):215-29, 2004.

Curlin, J. F. Antiinflamatorios No Esteroideos. En: Warfield, C. \& Fause, H. H. (Eds.). Diagnóstico y Tratamiento del Dolor. Barcelona, Masson, 2004. pp.246-50.

Daniels, S. E.; Bandy, D. P.; Christensen, S. E.; Boice, J.; Losada, M. C.; Liu, H.; Mehta, A. \& Peloso, P. M. Evaluation of the dose range of etoricoxib in an acute pain setting using the postoperative dental pain model. Clin. J. Pain, 27(1):1-8, 2011.

Grosser, T.; Smyth, E. \& Fitzgerald, G. A. Antiinflamatorios, Antipiréticos y Analgésicos; Farmacoterapia de la Gota. En: Brunton, L.; Chabner, B. \& Knollman, B. (Eds.). Goodman \& Gilman's Las Bases Farmacológicas de la Terapéutica. Cap. 34. $12^{\mathrm{a}}$ ed. Ciudad de México, Editorial Mc-Grall-Hill, 2011. pp. 959-1004

Nissen, S. E.; Yeomans, N. D.; Solomon, D. H.; Lüscher, T. F.; Libby, P.; Husni, M. E.; Graham, D. Y.; Borer, J. S.; Wisniewski, L. M.; Wolski, K. E.; Wang, Q.; Menon, V.; Ruschitzka, F.; Gaffney, M.; Beckerman, B.; Berger, M. F.; Bao, W.; Lincoff, A. M. \& PREClSION Trial Investigators. Cardiovascular Safety of Celecoxib, Naproxen, or Ibuprofen for Arthritis. N. Engl. J. Med., 375(26):2519-29, 2016.

Ong, C. K. \& Seymour, R. A. An evidence-based update of the use of analgesics in dentistry. Periodontol. 2000, 46:143-64, 2008.

Rodríguez Reyes, O.; García Cabrera, L.; Bosch Núñez, A. I. \& Inclán Acosta, A. Fisiopatología del dolor bucodental: una visión actualizada del tema. MEDISAN, 17(9):5079-85, 2013

Silva, R. C.; Riera, R. \& Saconato, H. Lumiracoxib for acute postoperative dental pain: a systematic review of randomized clinical trials. Sao Paulo Med. J., 129(5):335-45, 2011.

Corresponding author:

PhD Fatima Erendida Del Muro Casas

in Pharmacology Science

Professor in Academic Unit of Dentistry

Autonomous University of Zacatecas

MÉXICO

Email: fatimadelmurocasas@gmail.com

Received: 03-04-2018

Accepted: 30-05-2018 